\title{
Social and economic characteristics of ISPO certified oil palm smallholders
}

\author{
Mirawati Yanita ${ }^{1 *}$, and Rozaina Ningsih ${ }^{2}$ \\ ${ }^{1}$ Agribusiness Department, and CSSPO Jambi University Mendalo Darat KM 15, Indonesia \\ ${ }^{1,2}$ Agribusiness Department, Jambi University Mendalo Darat KM 15, Indonesia
}

\begin{abstract}
Oil palm plantations contribute to job creation and community welfare. Nevertheless, this commodity is still experiencing business sustainability problems among smallholders in Indonesia Certification Palm Oil (ISPO). This research studies the existing conditions of ISPO certified smallholders and has not been authenticated based on economic and social characteristics. The research was conducted in Batanghari Regency with the use of primary and secondary data. The result showed that the social aspects of smallholders who have ISPO certified are average in the productive age range. However, there are no differences in education at the primary level. As for the number of family members, smallholders who are certified than uncertified have a more significant number of family members. The farming experience of certified smallholders is lower than that of non-certified, related to the age of the crop owned to motivate and carry out sustainable agricultural practices. While from the economic aspect, based on the primary and other search points, the average number for certified is more concentrated with their palm oil cultivation by 73.86 percent than noncertified with diverse business activities. There are variations in the social and economic characteristics of certified and uncertified oil palm farmers. Good agricultural practices following the norms are necessary to ensure the sustainability of oil palm cultivation. In the future, smallholders are expected to encourage improved farming practices and improve their livelihood assets
\end{abstract}

\section{Introduction}

Oil Palm is currently the most important commercial crop globally $[1,2]$. The oil palm commodity business is a mainstay in most households as a source of income, especially in the tropics. In addition, this plant has also significantly increased revenues, generated employment, reduced poverty among farm and nonfarm households, and decreased malnutrition in the countryside [2,3]. Oil palm adoption allows rural families to have a good income independently. Global demand for vegetable oil as one of the oil palm derivative products is projected to increase in the coming decades due to population increases and revenue growth $[1,4]$. So in the future, to match this increase in demand, it is estimated that palm oil production will need to increase by 25 mill tons annually for the next decade [5].

\footnotetext{
*Corresponding author: mirawatiyanita@unja.ac.id
} 
According to [4], Indonesia is the leading oil palm producer in both production and land area globally. This position makes palm oil Indonesia's leading commodity, a significant source of income and employment, and the largest foreign exchange contributor as a plantation commodity. Indonesia is the world's largest exporter of palm oil today, with approximately 16 million workers. More than $40 \%$ of Indonesia's total oil palm land is not cultivated by large palm oil companies but by small and medium-sized family farms [6]. Some research shows that smallholders benefit from oil palm cultivation in higher household living standards, as oil palm is more profitable than traditional crops such as rice or rubber $[7,8]$.

Oil palm plantations contribute to job creation and community welfare. Nevertheless, this commodity is still experiencing business sustainability problems among smallholders. Several standard-setting and certification initiatives have grown over the past few years due to increased attention to sustainability. Compared to other commodities such as coffee or cocoa, sustainable palm oil is complicated to incentivize consumers because it often only forms a small part of the final product. But growing concerns about sustainability and increased public pressure on companies and governments have led to the emergence of certification standards and schemes in the palm oil sector. Through certification, oil palm, especially non-governmental oil palm, can be carried out sustainably.

ISPO standards are mandatory for plantation companies, plantations only without factories, and factories without farms while still volunteering for schemes and independent smallholder farmers [9]. Many previous studies about oil palm certification were conducted in response to these sustainability and more sustainable production practices concerns [1017]. But how explicitly the social and economic conditions of certified and uncertified farmers to implement good agricultural practices sustainably still need to be further reviewed. Based on Regulation Ministry of Agriculture No. 38/2020, oil palm smallholders have a land area of less than 25 ha [18]. However, the majority of smallholders have less than 4 ha. Therefore, the business scale is inadequate to cover modern agricultural practices with certification standards. Therefore, smallholders must have certs incorporated in groups such as Village Cooperatives (called Village Unit Cooperatives/KUD) and farmer groups to achieve a minimum scale of business to be certified. At the same time, this commodity is still experiencing business sustainability problems among smallholders in Indonesia Certification Palm Oil (ISPO). This research studies the existing conditions of ISPO certified smallholders and has not been authenticated based on economic and social characteristics.

\section{Methods}

The research was conducted in Batanghari Regency using primary and secondary data. The location selection was made deliberately assuming that Batanghari Regency is one of the largest palm oil plantation centres in Jambi province. Smallholders have been certified in the district and have not yet been approved in the village of Water Pump. A simple random sampling is applied so that each unit or fundamental unit of the population has the same opportunity to be selected as a sample [19]. In order to get smallholders respondents from the entire selection, we used a simple random sampling method in each population of ISPO certified smallholder farmers and non-certified smallholder farmers with indications of attention.

To maintain the heterogeneity of the sample group, the farmers who were the object of this study are devoted to oil palm smallholders whose crop age ranges from 10 - 20 years. Therefore, the social and economic aspects become concerned in this research whether smallholders are certified or not. The social element consists of age, level of education, number of family members, cultivation experiences, and land cultivation area. While from 
the economic side based on the combination pattern of smallholders income sources and the production quantity.

\section{Result and discussions}

In this study, the total number of farmers work on oil palm plantations with ISPO (Indonesian Sustainable Palm Oil) certification and those who work on oil palm plantations without a certificate is 63 farmers. Smallholder farmers who are independent or not based on social and economic aspects. The social elements are the age of farmers, the number of dependent family members, the level of education, the experience of farming, and the area of land owned. Furthermore, the pattern of farmers' income sources and the production of oil palm farming is considered in the economic aspect.

\subsection{Social aspects}

Age can affect smallholder's ability and way of thinking. It can be interpreted as productive farmers have physical and mental skills to produce higher productivity [20]. Abundant and healthy farmers have a faster cognitive ability to accept new things that are recommended. Likewise, older farmers will find it harder to take new things and decisionmaking. On the other hand, young farmers tend to be dynamic, so they get many valuable new experiences for their future development. Therefore, the age level can determine the productivity of the resulting crop, especially in farmers who do farming by relying on their physical abilities without hiring a labor force outside the family. The result showed that the social aspects of smallholders who have ISPO certified are average in the productive age range.

Consequences of the age of the agricultural labor force have attracted widespread attention, but the conclusions vary [21,22]. The ageing of the farm labor force intensifies the shortage of local farms, promoting technological evolution, which may positively impact agricultural production [23]. The positive impact of better production is expected to also encourage the sustainability of palm oil farming activities by conducting good agricultural practices.

Based on the results on 76 farmers in the research area, the age of farmers ranges from 25 years to 69 years. Table 1 below shows the proportion of smallholders based on the level of age in the research area. The most extensive distribution of farmer age samples in the research area for ISPO certified palm oil farmers is at the interval of 50 - 54 years age group of $25 \%$. At the same time, the age distribution of the largest sample farmers for non-certified palm oil farmers is at intervals of 45 - 49 years of age of $28.57 \%$. 
Table 1. Distribution of farmer samples by age group in research areas

\begin{tabular}{|c|c|c|c|c|}
\hline \multirow{2}{*}{$\begin{array}{c}\text { Age Group } \\
\text { (Year) }\end{array}$} & \multicolumn{2}{|c|}{$\begin{array}{c}\text { Oil Palm Smallholders } \\
\text { Certified }\end{array}$} & \multicolumn{2}{c|}{$\begin{array}{c}\text { Oil Palm Smallholders } \\
\text { Non-Certified }\end{array}$} \\
\cline { 2 - 5 } & $\begin{array}{c}\text { Amount of } \\
\text { Farmer }\end{array}$ & $\begin{array}{c}\text { Percentage } \\
(\%)\end{array}$ & $\begin{array}{c}\text { Amount of } \\
\text { Farmer }\end{array}$ & $\begin{array}{c}\text { Percentage } \\
\text { (\%) }\end{array}$ \\
\hline $25-29$ & 1 & 3,57 & 0 & 0 \\
\hline $30-34$ & 0 & 0,00 & 4 & 11,43 \\
\hline $35-39$ & 3 & 10,71 & 2 & 5,71 \\
\hline $40-44$ & 5 & 17,86 & 5 & 14,29 \\
\hline $45-49$ & 3 & 10,71 & 10 & 28,57 \\
\hline $50-54$ & 7 & 25,00 & 4 & 11,43 \\
\hline $55-59$ & 4 & 14,29 & 4 & 11,43 \\
\hline $60-64$ & 4 & 14,29 & 3 & 8,57 \\
\hline $65-69$ & 1 & 3,57 & 3 & 8,57 \\
\hline Total & 28 & 100 & 35 & 100 \\
\hline
\end{tabular}

Source; Survey Data, 2020

Education can affect the creativity and ability of a person, who is a farmer, in accepting innovations and influencing the behaviour of farmers in managing their farming. The education in question is a formal education that farmers have in which to participate. There is some agreement in the literature that education significantly influences technological innovations in agriculture $[24,25]$. Thus level of education is essential if farmers are to adopt technologies to be sustainable. More about the importance of education [26] stated that extension services should cover more farmers who should be encouraged to improvise oil palm farming practices and raise their livelihood assets.

The level of education of farmers in the research area varies from elementary to undergraduate level. However, most farmers get an education at the elementary level of $67.86 \%$ for ISPO-certified oil palm farmers and $71.43 \%$ for non-certified palm oil farmers. Limitations of education level will affect the way of thinking, accepting, or rejecting new things. The higher the level of education of farmers, the wiser it will be to manage their farming, affecting agriculture production, quality, and quantity. The results showed that the level of education of farmers in the research area is still relatively low. The Distribution of Smallholders Education levels is shown in table 2 below.

Table 2. Distribution of farmer samples by education level in research area.

\begin{tabular}{|l|c|c|c|c|}
\hline \multirow{2}{*}{ Education.Level } & \multicolumn{2}{|c|}{$\begin{array}{c}\text { Oil Palm Smallholders } \\
\text { Certified }\end{array}$} & \multicolumn{2}{c|}{$\begin{array}{c}\text { Oil Palm Smallholders } \\
\text { Non-Certified }\end{array}$} \\
\cline { 2 - 5 } & $\begin{array}{c}\text { Amount Of } \\
\text { Smallholders }\end{array}$ & $\begin{array}{c}\text { Percentage } \\
(\%)\end{array}$ & $\begin{array}{c}\text { Amount Of } \\
\text { Smallholders }\end{array}$ & $\begin{array}{c}\text { Percentage } \\
\text { (\%) }\end{array}$ \\
\hline Primary & 19 & 67,86 & 25 & 71,43 \\
\hline Junior & 6 & 21,43 & 7 & 20,00 \\
\hline Senior & 2 & 7,14 & 3 & 8,57 \\
\hline Bachelor & 1 & 3,57 & 0 & 0 \\
\hline Total & 28 & 100 & 35 & 100 \\
\hline
\end{tabular}

Source: Survey Data, 2020 
Many family members are closely related to income, especially household consumption and other purposes related to the family's availability of labor. Therefore, the more family members, the more delivery can be used in farming production activities, and vice versa. In addition, the number of family members also describes the economic burden that each family carries on the welfare of family members. The number of family members here is intended by the number of dependents and are in one family home. As for the number of family members, smallholders who are certified than uncertified have a more significant number of family members.

Table 3. Distribution of farmer samples by family member amount level

\begin{tabular}{|c|c|c|c|c|}
\hline \multirow{2}{*}{$\begin{array}{c}\text { Family } \\
\text { Member }\end{array}$} & \multicolumn{2}{|c|}{ Oil Palm Smallholders Certified } & \multicolumn{2}{c|}{ Oil Palm Smallholders Non-Certified } \\
\cline { 2 - 5 } & $\begin{array}{c}\text { Amount Of } \\
\text { Smallholders }\end{array}$ & $\begin{array}{c}\text { Percentage } \\
\text { (\%) }\end{array}$ & $\begin{array}{c}\text { Amount Of } \\
\text { Smallholders }\end{array}$ & $\begin{array}{c}\text { Percentage } \\
\text { (\%) }\end{array}$ \\
\hline 2 & 9 & 32,14 & 9 & 25,71 \\
\hline 3 & 13 & 46,43 & 18 & 51,43 \\
\hline 4 & 4 & 14,29 & 6 & 17,14 \\
\hline 5 & 2 & 7,14 & 2 & 5,72 \\
\hline Total & 28 & 100 & 35 & 100 \\
\hline
\end{tabular}

Source: Survey data, 2020

According to Table 3, the number of farming family members in the area varies from 2 to 5 people. However, most of the sample farmers have a family of 3 people. For example, in ISPO certified oil palm farmers, 13 farmers or 46.43 percent have a family of 3 people, and in non-certified oil palm farmers, 18 farmers or $51.43 \%$ have a family of 3 people. The number of family members is very influential in managing an economic activity, especially on economic activities in the cultivation. However, oil palm farming is the head of the family, so the workforce is outside the family.

Farming experience is one of the most determining factors of a business's success. It is helpful to be used in business considerations and decision making in the production process, management, and marketing of results. Therefore, the more extended the experience that farmers have in farming, the more skilled farmers will be in managing their cultivation. The farming experience in sample farmers in research areas is measured since the first time farmers farmed palm oil declared in years. The distribution of sample farmers based on palm oil farming experience is shown in Table 4.

The farming experience of certified smallholders is lower than that of non-certified, related to the age of the crop owned to motivate and carry out sustainable agricultural practices. Experience in farming in ISPO certified palm oil farmers has the most significant percentage with ten years of farming experience. In contrast, non-certified palm oil farmers have farming experience with the largest share of $28.56 \%$ with 13 years of farming experience. It shows that farmers are experienced enough in farming palm oil. Based on the study results, the length of farming experience also indicates the age of oil palm crops in each farmer's farm. Long farming experience will affect farmers' decision-making in allocating factors that will impact the sustainability of cultivation related to good agricultural practices. 
Table 4. Distribution of farmer samples by the farming experience

\begin{tabular}{|c|c|c|c|c|}
\hline \multirow{2}{*}{$\begin{array}{c}\text { Farming } \\
\text { Experience } \\
\text { (Year) }\end{array}$} & \multicolumn{2}{|c|}{ Oil Palm Smallholders Certified } & \multicolumn{2}{c|}{ Oil Palm Smallholders Non- Certified } \\
\cline { 2 - 5 } & Amount of Farmer & $\begin{array}{c}\text { Percentage } \\
(\%)\end{array}$ & Amount of Farmer & $\begin{array}{c}\text { Percentage } \\
(\%)\end{array}$ \\
\hline 10 & 11 & 39,28 & 8 & 22,86 \\
\hline 11 & 4 & 14,29 & 5 & 14,29 \\
\hline 12 & 5 & 17,86 & 4 & 11,43 \\
\hline 13 & 6 & 21,43 & 10 & 28,56 \\
\hline 14 & 1 & 3,57 & 4 & 11,43 \\
\hline 15 & 1 & 3,57 & 4 & 11,43 \\
\hline Total & 28 & 100 & 35 & 100 \\
\hline
\end{tabular}

Source: Survey Data, 2020

\subsection{Economic aspects}

Bajubang sub-district is one of the central areas of palm oil production in Batanghari Regency. Palm oil farming in Bajubang sub-district consists of ISPO-certified palm oil farming that applies the principle of sustainable palm oil and non-certified palm oil farming that has not implemented sustainable palm oil. ISPO certification was established in 2011, but oil palm farmers in Bajubang Sub-district signed up for certification in 2017 and obtained official certification in 2018.

The number of farmers who have been ISPO certified is only 75 farmers or only $44.12 \%$ of the total oil palm farmers in the research area (170 farmers). The low number of ISPO certified farmers is due to the obligation of oil palm farmers to apply the principles and criteria contained in ISPO certification and insufficient budget to finance all farmers in obtaining certification. The use of production factors in ISPO-certified palm oil farming and non-certified palm oil farming in Bajubang sub-district consists of land use, fertilizer, pesticides, and labor. The use of sample farmer production factors in the research area can be seen in table 5 .

Table 5. The use of production factors in the research area

\begin{tabular}{|c|c|c|c|c|}
\hline No & Description & $\begin{array}{c}\text { Oil Palm } \\
\text { Smallholders } \\
\text { Certified }\end{array}$ & $\begin{array}{c}\text { Oil Palm } \\
\text { Smallholders } \\
\text { Non-Certified }\end{array}$ & $\begin{array}{c}\text { Norm } \\
\text { Input Used }\end{array}$ \\
\hline 1. & Land Area (Ha/Farmer) & 3,30 & 2,01 & - \\
\hline 2. & Fertilizer & & & 204 \\
\hline & - Urea & 382,9 & 132,5 & 340 \\
\hline & - NPK & 308,3 & 133,9 & 272 \\
\hline
\end{tabular}




\begin{tabular}{|c|c|c|c|c|}
\hline No & Description & $\begin{array}{c}\text { Oil Palm } \\
\text { Smallholders } \\
\text { Certified }\end{array}$ & $\begin{array}{c}\text { Oil Palm } \\
\text { Smallholders } \\
\text { Non-Certified }\end{array}$ & $\begin{array}{c}\text { Norm } \\
\text { Input Used }\end{array}$ \\
\hline & - TSP & 390,6 & 136,8 & 306 \\
\hline & - Dolomit & 108,4 & 0 & 272 \\
\hline 3. & - Organic & 214,9 & 0 & - \\
\hline 4. & Total Fertilizer (Kg/Ha/Year) & $1.758,2$ & 551,2 & 1.394 \\
\hline & $\begin{array}{c}\text { Lesticide (Liter/Ha/Year) } \\
\text { - Family Labor force }\end{array}$ & 5,4 & 10 & 10 \\
\hline & $\begin{array}{c}\text { - non-family Lbor force } \\
\text { Total labor Force } \\
\text { (workday/Ha/Year }\end{array}$ & 0,2 & 0,8 & - \\
\hline 5. & $\begin{array}{c}\text { Agricultural tool } \\
\text { (unit/Ha/Year) }\end{array}$ & 12 & 0,4 & - \\
\hline
\end{tabular}

Source: Survey Data, 2020

While from the economic aspect, based on the primary data and other search points, the average for certified is more concentrated with their palm oil cultivation by 71.43 percent than non-certified with diverse business activities. The pattern of smallholder's income sources bases on five patterns. Table 6 below shows the ways of smallholder's income sources.

Table 6. Distribution smallholder's income sources in the research area.

\begin{tabular}{|c|c|c|c|c|}
\hline \multirow{2}{*}{ Income Sources } & \multicolumn{2}{|c|}{$\begin{array}{c}\text { Oil Palm Smallholders } \\
\text { Certified }\end{array}$} & \multicolumn{2}{c|}{$\begin{array}{c}\text { Oil Palm Smallholders } \\
\text { Non-Certified }\end{array}$} \\
\cline { 2 - 5 } & $\begin{array}{c}\text { Amount of } \\
\text { Smallholders }\end{array}$ & $\begin{array}{c}\text { Percentage } \\
\text { (\%) }\end{array}$ & $\begin{array}{c}\text { Amount of } \\
\text { Smallholders }\end{array}$ & $\begin{array}{c}\text { Percentage } \\
\text { (\%) }\end{array}$ \\
\hline Oil Palm & 20 & 71,43 & 19 & 54,28 \\
\hline $\begin{array}{c}\text { OilPalm }+ \\
\text { Rubber }\end{array}$ & 0 & 0 & 5 & 14,28 \\
\hline $\begin{array}{c}\text { Oil Palm }+ \\
\text { Rubber+ } \\
\text { LIvestock }\end{array}$ & 0 & 0 & 8 & 22,86 \\
\hline $\begin{array}{c}\text { Oil Palm }+ \\
\text { Melon }\end{array}$ & 3 & 10,72 & 3 & 8,57 \\
\hline $\begin{array}{c}\text { Oil Palm }+ \\
\text { Livestock }\end{array}$ & 3 & 17,85 & 2 & 5,71 \\
\hline Total & 28 & 100 & 35 & 100 \\
\hline
\end{tabular}

Source: Survey Data, 2020 
Based on table 6, most farmers who work on palm oil for certified farmers are 71.43 percent. The rest are just working on oil palm and melon patterns as well as oil palm and livestock. On the contrary, uncertified farmers have more diversity of income source patterns. While for oil palm production, the smallholders who own certified and non-certified depend on the age of the oil palm.

Production in one year ranges from 7-41 tons, for certified farmers as much as 35.71 per cent with 17-26 tons. In comparison, uncertified farmers produce the most bunches of fresh fruit by 12-16 tons or 57, 14 percent of farmers. It indicates that the production rate of fresh fruit bunches is higher. Conditions can be explained that the production of certified farmers is 23.92 tons/ha compared to non-certification that can only produce as much as 11.42 tons / Ha. This production difference is in line with this research [27] that there are differences in treatment between certified and uncertified palm oil.

\section{Conclusion}

There are variations in the social and economic characteristics of certified and uncertified palm oil farmers. Good agricultural practices following the norms are necessary to ensure the sustainability of palm oil farming. In the future, farmers are expected to encourage improved farming practices and improve their livelihood assets.

Acknowledgment. This research was funded by Fakultas Pertanian Universitas Jambi through PNBP fund in 2020 .

\section{References}

1. D. Byerlee, W. P. Falcon, R. L. Naylor, The Tropical Oil Crop Revolution: : Food, Feed, Fuel, and Forest. (Oxford Univ.Press New York, 2017)

2. M. Qaim, K. T. Sibhatu, H. Siregar, I. Grass, Annu. Rev. Resour. Econ., 12 (2020)

3. K. T. Sibhatu, Front. Sustain. Food Syst., 3 (2019)

4. FAO (Food Agric. Organ.)., "Crops," 2019

5. M. Romero, M. Wollni, K. Rudolf, R. Asnawi, B. Irawan, World Dev., 124 (2019)

6. M. Euler, V. Krishna, S. Schwarze, World Dev., xx (2017)

7. V. Krishna, M. Euler, H. Siregar, M. Qaim, Agric. Econ., 00 (2017)

8. C. Kubitza, V. V. Krishna, Z. Alamsyah, M. Qaim., Hum. Ecol., (2018)

9. S. Hutabarat, Agro Ekon., 28, 2 (2017)

10. T. Santika et al., Nat. Sustain., (2020)

11. E. Apriani, Y. Kim, L. A. Fisher, H. Baral, Land use policy, 99 (2020)

12. S. Hutabarat, M. Slingerland, L. Dries, J. Environ. Dev., 28, 3 (2019)

13. N. Saadun et al., Land use policy, 72 (2017)

14. N. Nurliza, E. Dolorosa, J. Sustain. Dev., 10, 1 (2017)

15. A. Rival, D. Montet, D. Pioch, OCL J., 23, 6 (2016)

16. C. Brandi, T. C. C. H. S. S. L. W. Hannah, H. Wiese, Sustainability certification in the Indonesian palm oil sector : benefits and challenges for smallholders, no. 74. (German Development Institute, 2013)

17. J. Smith, Science Journals by AAAS, (2018)

18. Implementing Indonesian Sustainable Oil Palm Plantation Certification, (Ministry of Agriculture. Indonesia, 2020)

19. Abdi, U. Rianse, Metodologi Penelitian Sosial dan Ekonomi: Teori dan Aplikasi. (Bandung. Alfabeta, 2012)

20. G. Guo, Q. Wen, J. Zhu, Math. Probl. Eng., (2015) 
21. J. Liu, C. Zhang, R. Hu, X. Zhu, J. Cai, Sustainability, 11, 6246 (2019)

22. Z. Qiao, X. Huo, B. Zhang, J. Econ. Surv., 35 (2018)

23. J. Li, Z. Feng, Q. Wu, Agrotech Econ., 8 (2018)

24. M. N. Asadullah, CSAE WPS, 10 (2005)

25. A.S. Langyintuo, M. Mekuria, "Modelling agricultural technology adoption using the software STATA," in International Maize and Wheat Improvement Centre (CYMMT), (2005)

26. J. Anaglo, S. Boateng, F. Swanzy, J. Biol. Agric. Healthc., 4 (2014)

27. D. Chalil, S. F. Sidique, R. Barus, J. AGRISEP, 8, 2 (2019) 